TEME, г. XLI, бр. 2, април - јун 2017, стр. 301-314

Прегледни рад

DOI: $10.22190 /$ TEME1702301S

Примљено: 21. 4. 2016.

UDK 364.633:316.624

Ревидирана верзија: 29. 2. 2017.

Одобрено за штампу: 15. 6. 2017.

\title{
РАЗВОЈ ПРИМАРНЕ ПРЕВЕНЦИЈЕ СЕКСУАЛНОГ НАСИЉА У СВЕТУ
}

\author{
Биљана Симеуновић-Патић \\ Криминалистичко-полицијска академија, Београд, Србија \\ biljasp@hotmail.com
}

\begin{abstract}
Апстракт
Мада је питањима етиологије и контроле сексуалног насиља последњих деценија посвећена знатна научна пажња, оно је и даље проблем који широм света погађа знатан део популације, поготово младе особе женског пола. Упоредо са пооштравањем репресивних одговора на сексуалне деликте и унапређивањем мера заштите и помоћи жртвама, расте интересовање за развијање превентивних програма у овој области, укључујући и дуго занемариване програме примарне превенције. Имајући у виду природу, тешке и дугорочне последице сексуалне виктимизације, као и правилност да овај облик виктимитета карактерише велика тамна бројка, примарна превенција представља одговор који је оптималан, економичан и онај који у овом тренутку највише обећава, упркос укорењеном скептицизму према примарној превенцији и проблемима евалуације примарно превентивних мера. У раду се разматрају домети и значај примарне превенције у спектру друштвених одговора на сексуално насиље, као и важност социо-еколошке превентивне платформе оличене у склопу мера усмерених на појединце и заједнице, с циљем промене културних норми и ставова према сексуалном насиљу и насиљу према женама. Посебна пажња поклоњена је моделима превенције утемељеним на актуелним сазнањима о структури фактора ризика и заштите од сексуалног насиља, односно примарно превентивним интервенцијама које се потврђују као ефективне.
\end{abstract}

Кључне речи: сексуално насиље, сексуална виктимизација, фактори сексуалног насиља, социо-еколошки модел насиља, примарна превенција.

\section{DEVELOPMENT OF SEXUAL VIOLENCE PRIMARY PREVENTION AROUND THE WORLD}

\begin{abstract}
Although the issues of etiology and control of sexual violence have attracted considerable scientific attention over the past decades sexual victimization is still a serious problem in many countries around the world affecting particularly young females. Along with the tightening of repressive responses toward sexual crimes and improvements of victim protection, assistance and support measures there is a rising interest for development of prevention programs, including a long neglected primary
\end{abstract}


prevention interventions. Bearing in mind the nature of sexual victimisation, its severe and long-lasting consequences and its huge dark figure, primary prevention appears to be optimal, cost-effective and most promising response in this moment, regardless of the common scepticism around the effectiveness and evaluation of primary prevention initiatives. The paper discusses the scope and significance of primary prevention within the spectrum of societal responses toward sexual violence, as well as the importance of socioecological platform for sexual violence prevention comprising of the measures that target both the individuals and communities aiming to change cultural norms and attitudes supportive of sexual violence and violence against women. Particular attention is paid to contemporary prevention approaches and models based on empirical evidence on risk and protective factors, and to evidentially effective primary prevention interventions.

Key words: sexual violence, sexual victimisation, factors of sexual violence, socio-ecological model of violence, primary prevention.

\section{УВОДНЕ НАПОМЕНЕ}

Појам сексуалног насиља, којим се означавају различити акти којима се напада на полну слободу, односно сексуални интегритет другог, разнолико се одређује. Светска здравствена организација дефинише сексуално насиље као „сваки сексуални чин или покушај остваривања сексуалног чина, нежељени сексуални коментар или предлог, односно трговину или другу радњу усмерену против сексуалности другог, извршене применом силе или претње, од стране било ког лица, без обзира на његов однос са жртвом и независно од окружења у којем се врши, укључујући дом и радно место, али се не ограничавајући на њих" (Jewkes, Sen \& Garcia-Moreno, 2002, p. 149). Према нешто ужој дефиницији америчког Националног центра за превенцију и контролу повреда, сексуално насиље представља „извршен или покушан сексуални чин над другим без жртвине слободно дате сагласности, или над лицем које није у стању да сагласност да или да је одбије”, а укључује: присилну пенетрацију или пенетрацију олакшану употребом алкохола или дрога, нефизичку принуду на нежељену пенетрацију, намерно сексуално додиривање, бесконтактне акте сексуалне природе, као и принуђивање на сексуалне активности с трећим лицем (Basile, Smith, Breiding, Black, Mahendra, 2014 , p. 11). Најкраће, појам сексуалног насиља означава извршену или покушану обљубу или другу полну радњу над особом која на њу није пристала или није била у стању да се слободно с њом сагласи. Сексуално насиље подразумева напад којим се повређује полна слобода или полно достојанство другог, а варира од сексуалног узнемиравања до силовања.

Светска здравствена организација означила је сексуално насиље као „глобални јавноздравствени проблем епидемијских размера”, процењујући да је више од 35\% жена у свету доживело физичко или сексуално насиље у партнерском односу, или сексуално насиље из- 
ван партнерског односа (World Health Organization, 2013, p. 3, 20). Емпиријски налази конзистентно показују да су жртве доминантно женског, а извршиоци мушког пола, као и да последице сексуалног насиља могу бити врло тешке и укључивати трајне негативне промене у функционисању жртава на телесном, психичком и социјалном плану. Сексуалним насиљем су знатно погођена и малолетна лица (Brown \& Saied-Tessier, 2015, pp. 8-9) која трпе особито тешке последице виктимизације. Тежина последица које погађају директне и индиректне жртве, али и шире друштво, уз незадовољавајући учинак пооштравања репресије и мера терцијарне превенције према сексуалним преступницима, упућује на значај примарне превенције у овој области, која у последње време с разлогом почиње да добија примат у спектру друштвених одговора.

Под примарном превенцијом сексуалног насиља може се разумети скуп активности и мера управљених на редукцију инциденце сексуалног насиља, односно скуп превентивних интервенција које се предузимају пре него што се насиље догоди, а којима се циља на општу популацију или онај њен сегмент који се, с обзиром на демографска обележја, налази у повишеном ризику од вршења или страдања од сексуалног насиља (упореди: Harvey, Garcia-Moreno, Butchart, 2007, p. 5; DeGue, Valle, Holt, Massetti, Matjasko, Tharp, 2014, p. 347). Примарнопревентивне интервенције се идеално темеље на солидном теоријском објашњењу проблема, а у његовом одсуству, на постојећим знањима о факторима ризика и заштите. Преовладава схватање да је сексуална насилност детерминисана сплетом чинилаца на индивидуалној, интерперсоналној и социјалној равни, при чему се сматра да културне вредности и норме, које обликују понашање појединца, доприносе одржавању насиља тако што га оправдавају, подстичу или пак обесхрабрују индивидуалне позитивне промене (Davis, Parks \& Cohen, 2006, p. 4). Амбициозна примарна превенција циља управо на системске узроке и промене на нивоу друштва (Wall, 2013, p. 2), као једини пут стварања трајно сигурнијих окружења у партнерском односу, дому, суседству, школи и на радном месту (Davis et al, 2006, p. 3).

Примарна превенција сексуалног насиља претежно је усмерена на промене културних норми и ставова о сексуалном насиљу и родним улогама, и ослања се превасходно на едукативне програме. Културне норме чијој се промени тежи укључују оне које дефинишу женску родну улогу којом се постављају ограничења у супротстављању вољи мушкарца и намеће кривица за сексуалну виктимизацију, оне везане за мушку родну улогу којом се подстиче усмереност на успех у сексуалном авантуризму и успостављању доминације над женом, као и норме о личној и породичној приватности које налажу ћутање о сексуалном насиљу (Davis et al, 2006, p. 4). Део савремених примарнопревентивних програма усмерен је и на подизање свести о ри- 
зику виктимизације или на подстицање личне иницијативе у унапређењу самозаштите избегавањем ризичних ситуација или обучавањем жена за пружање отпора нападачу савладавањем техника самоодбране и вештина превазилажења психолошких баријера за пружање активног отпора који, како показују неки налази, увећава жртвине шансе да избегне силовање и телесно повређивање (Ullman, 2010, p. 727).

Ослањање на примарнопревентивне интервенције, које обично подразумевају јавноздравствени приступ проблему, ${ }^{1}$ релативно је нов развој у области спречавања насиља, још увек суочен са изазовима у дизајнирању, имплементацији и оцени ефеката, али и теоријској утемељености. Литература обилује различитим био-социјалним, психолошким, феминистичким и другим моделима објашњења узрочности сексуалног насиља, при чему су неки међусобно непомирљиви и искључиви. Но, на темељу постојећих емпиријских налаза, идентификован је већи број фактора ризика, а сазнања о њима за сада компензују недостатак целовите теоријске елаборације.

\section{ФАКТОРИ СЕКСУАЛНОГ НАСИЉА}

Сматра се да су међу факторима ризика за сексуално насилништво на индивидуалном нивоу слаба самоконтрола, девијантне сексуалне склоности, преокупираност сексом, снижена способност емпатије, подржавајући ставови према сексуалном насиљу, мизогинија, дефицит интимности и склоност злоупотреби психоактивних супстанци (Mercado \& Ogloff, 2007; Hanson \& Harris, 2013).

Поред индивидуалних фактора ризика, ${ }^{2}$ на појаву сексуалног насиља утичу и различити микросоцијални и макросоцијални чиниоци, што је подржано емпиријским налазима о разликама у преваленци сексуалног насиља између локалних заједница и држава (World Health Organization, 2013). Стога социо-еколошки модел структуре фактора насиља, утемељен на разумевању људског понашања као обликованог на више нивоа (Casey \& Lindhorst, 2009) и концепцијски отворен оквир фактора ризика и заштите у индивидуалном и социјалном домену, представља добар основ за сагледавање узрочности, али и конципирање превенције сексуалног насиља.

\footnotetext{
${ }^{1}$ Превенција заснована на јавноздравственом приступу укључује фазе дефинисања проблема, утврђивања фактора ризика и заштите, развијања и тестирања програма и обезбеђивања да програм који је ефикасан буде широко прихваћен и адекватно имплементиран (Centers for Disease Control and Prevention, 2004, pp. 2-3).

${ }^{2}$ Међу индивидуалним факторима сексуалног злостављања деце значајно место имају и девијантна сексуална преференција према деци, емоционална конгруенција са дететом и погрешно уверење да су деца кадра да доносе одлуке у вези са сексуалном активношћу (Whitakeret al., 2008).
} 
Еколошки модел насиља представљен у Извештају Светске здравствене организације о насиљу и здрављу из 2002. године укључује факторе ризика који делују на индивидуалном, интерперсоналном, нивоу локалне заједнице и нивоу друштва (Dahlberg \& Krug, 2002). Специфични фактори на индивидуалном нивоу укључују биолошке чиниоце, склоност употреби алкохола или дрога, ставове и уверења која подржавају сексуално насиље, импулсивност, антисоцијалне тенденције, непријатељство према женама, сексуално злостављање у детињству и насиље у примарној породици (Dahlberg \& Krug, 2002; Jewkeset al, 2002). На интерперсоналној равни делују чиниоци посредством којих вршњаци, пријатељи, партнери и чланови породице утичу на понашање појединца. На нивоу локалне заједнице делују фактори који одређују ризик виктимизације у различитим социјалним окружењима (у школи, суседству итд.), док фактори ризика на нивоу друштва укључују макрочиниоце попут културних уверења, друштвених норми, економских или социјалних политика које доприносе неједнакости људи и међугрупном јазу (Dahlberg \& Krug, 2002).

Еколошки модел структуре фактора од кључног је значаја за примарну превенцију насиља јер промовише целовит приступ спектру чинилаца у међуутицају. Превентивне мере и активности укључују деловање како на индивидуалне тако и на факторе ризика на интерперсоналној равни интевенцијама попут породичне терапије, обуке у родитељским вештинама или обуке за интервенисање у улози очевица насиља, као и на факторе на нивоу заједнице и друштва интервенцијама усмереним на амбијенталне и микросистемске чиниоце, али и промену релевантних нормативних оквира, јавних политика, и према насиљу подржавајућих културних норми (Centers for Disease Control and Prevention, 2004, pp. 5-6). Овај модел ће извесно бити надограђиван, посебно на темељу сазнања о факторима заштите од сексуалног насиља, која су још увек оскудна. ${ }^{3}$

За развој примарнопревентивних интервенција значајно је и утврђивање кључних констелација фактора ризика. Тарп (Tharp) и сарадници су, рецимо, на темељу систематског истраживања чинилаца ризика од сексуалног насиља идентификовали две кључне констелације фактора дуж различитих домена: присуство и прихватьивост насиља и нездрава сексуална понашаға, искуства или ставови (Tharp, DeGue, Valle, Brookmeyer, Massetti \& Matjasko, 2012). Прва констелација обухвата следеће факторе ризика: на нивоу појединца прихватљивост насиља, раније вршење и виктимизацију сексуалним

\footnotetext{
${ }^{3}$ У литератури се углавном упућује на неколико њих: добре вештине родитеља у решавању породичних проблема, емоционалну повезаност, развијену емпатију и добро академско постигнуће (види: Tharp et al., 2012).
} 
насиљем; на породичном и нивоу партнерског односа - сукобе и злостављање у примарној породици и конфликтан однос са партнером; на нивоу вршњачке групе - припадање банди и дружење са особама које врше или подржавају сексуално насиље. Друга кључна констелација на индивидуалном нивоу укључује као факторе ризика вишеструке сексуалне везе, имперсоналан секс, рано упуштање у сексуалне активности, непријатељство према супротном полу, а на нивоу вршњачке групе изложеност сексуално агресивним вршњацима и притисак вршњака ка предузимању сексуалних активности (Tharp et al., 2012, p. 142).

\section{ФОРМЕ, ДЕЛОТВОРНОСТ И ПЕРСПЕКТИВЕ ПРИМАРНОПРЕВЕНТИВНИХ АКТИВНОСТИ И МЕРА}

Примарнопревентивни програми најчешће имају формат едукације чија је циљна група или мушка омладина (ради промене подржавајућих ставова према неједнакости полова и сексуалном насиљу) ${ }^{4}$, или женска популација (ради унапређења самозаштите подизањем свести о ризичним ситуацијама или обуком у вештинама самоодбране), или су то особе оба пола, као субјекти кадри да мењају социјалне норме и вршњачку културу толерантну на злостављање, односно као потенцијални актери ситуационе превенције.

Охрабрујући су резултати евалуација неких програма за младе чији је циљ унапређење вештина оних који се затекну као очевици у ризичним ситуацијама (в. Daigle \& Fisher, 2010; DeGue et al., 2014), као и налази који потврђују делотворност појединих превентивних програма намењених деци и младима, посебно оних посвећених унапређењу самозаштите (Zwi et al., 2008; Finkelhor, 2009, према: Brown \& Saied-Tessier, 2015, p. 15). Оно што онеспокојава јесте чињеница да је евалуација и даље болна тачка примарне превенције. Превентивне активности се каткад промовишу без снажне емпиријске потврде делотворности (Townsend, 2012, према: Dickson, \& Willis, 2015), а преовлађујући фокус евалуација чешће је на непосредним променама у знању и ставовима, а ређе на променама инциденце сексуалног насиља у дужем постинтервенцијском периоду (Dickson, \& Willis, 2015, p. 17).

Систематска анализа примарнопревентивних интервенција у области сексуалног насиља који су били предмет 140 евалуацијских студија објављених између јануара 1985. и маја 2012. године, а коју су спровели Диг (DeGue) и сарадници (DeGue et al., 2014) показала је

\footnotetext{
${ }^{4}$ Показује се да су програми са специфичним садржајем попут родне социјализације, чињеница и митова о силовању и начина снижавања ризика ефективнији од оних управљених на развијање емпатије (Dickson \& Willis, 2015).
} 
да је развој у овој области далеко од задовољавајућег. Утврђено је да је четвртина оцењених интервенција без ефекта или потенцијално штетна, њих преко 40\% има мешовит учинак, а свега $28 \%$ има позитивне резултате на свим мереним исходима. Показало се да учинковитост едукацијске интервенције зависи и од њеног трајања, тј. да једнократни и кратки програми не доводе до одрживих позитивних промена. Један од важних закључака студије односи се на потребу за унапређењем евалуацијских истраживања - због ограничења у примењеном методу евалуације, за чак три четвртине студија констатовано је да оскудевају у налазима релевантним за оцену ефективности програма (DeGue et al., 2014, p. 352). Међу интервенцијама за које је потврђена делотворност и одрживост учинака јесу, поред америчког Закона о спречавању насиља над женама (The Violence Against Women $A c t)$ из 1994. године, којим су пооштрене казне за сексуално и родно засновано насиље и обезбеђено финансирање истраживања, едукације, превенције и програма помоћи жртвама, и два програма превенције намењена деци средњошколског узраста, о којима ће укратко бити речи у наставку.

Програм под називом „Безбедни љубавни састанци” (Safe Dates), који се у САД-у и неким другим државама спроводи од 90-их година, усмерен је на превенцију насиља у романтичним везама, а његове компоненте су школске активности, као примарнопревентивне, и активности у заједници као примарно и секундарно превентивне. Школске активности спроводе се кроз десет 50-минутних сесија, позоришну игру и такмичења с постер-презентацијама. Непосредни циљеви програма су промена норми адолесцената о насиљу у везама и родним улогама, развијање вештина решавања сукоба у партнерском односу и вештина пружања вршњачке помоћи, као и развијање свести код потенцијалних жртава и извршилаца да им је потребна помоћ и охрабривање да је потраже. У сесијама посвећеним темама: дефинисање брижних односа и злостављања у вези; разлози због којих људи врше злостављьње; како помоћи пријатељима; превазилажење родних стереотипа; равнотежа моћи кроз комуникаиију; како се осећамо и како поступамо и превенција сексуалног злоставља$\mapsto b a$, ученици кроз предавања, студије случаја, дискусију у малим групама и писане вежбе усвајају знања о сексуалном насиљу и насилном односу, начину на који родни стереотипи промовишу насиље и како могу помоћи злостављаним вршњацима, а кроз игре улога овладавају вештинама успешне комуникације, препознавања и контроле љутње и пружања подршке злостављаним вршњацима. Програмске активности у заједници укључују поделу писаног материјала родитељима, обуку наставника и установљавање услуга за младе COC линија, група за подршку и др. (Foshee, Bauman, Arriga, Helms, 
Koch \& Linder, 1998). Поред потврђене делотворности, ${ }^{5}$ врлина програма је и то што се може спроводити и самостално и уклопљен у друге курикулуме.

Други примарнопревентивни програм чију су једну компоненту Диг и сарадници (2014) означили ефективном носи назив „Померање граница" (Shifting Boundaries), а осмишљен је у САД-у почетком 2000-их. Реч је о двокомпонентном програму намењеном млађим средњошколцима. Прва компонента укључује шест учионичких сесија кроз које се, током 6-10 недеља, подиже свест и знање о сексуалном злостављању и конструкцији родних улога, промовишу просоцијални и јачају негативни ставови према злостављању, осветљава улога очевидаца злостављања и наглашавају последице које погађају учиниоце. Друга програмска компонента спроводи се на нивоу и у простору школе и укључује ревизију школских протокола за откривање и реаговање у ситуацијама сексуалног злостављања, постављање постера ради подизања свести и стопе пријављивања насиља, идентификовање жаришних локација и појачано надгледање школског простора. Потврђено је да интервенција на нивоу школског окружења (али не и учионичке сесије) доприноси редуковању и вршења и виктимизације вршњачким сексуалним насиљем, као и редукцији сексуалне виктимизације у партнерском односу (Taylor, Stein, Woods \& Mumford, 2011).

Едукативни програми обично нису скупи и могу се једноставно сачинити и имплементирати, но они су само једна компонента примарне превенције, недовољна за постизање њених циљева који укључују колективну промену ставова и понашања, а не пуко подизање свести и знања (Quadara \& Wall, 2012, p. 5). Примарнопревентивни програми треба да циљају на све оне факторе који посредством социјализације и различитих друштвених процеса учвршћују подржавајуће ставове према насиљу, неједнакости полова и ригидним родним улогама, концепт мужевности карактерисан сексуалним авантуризмом и успостављањем контроле и доминације над женом, али и праксе којима се жене објективизују и одржава структурална неједнакост.

Несумњиво утицајан фактор сексуалног насиља јесте културално подржавање неједнакости на основу пола, са пратећом родном социјализацијом, која је, стицајем специфичних друштвено-историјских околности, безмало извитоперила сврсисходност полног диморфизма код људи. Литература обилује налазима да силовање из перспективе извршилаца има одређену социјалну функцију - успостав-

\footnotetext{
${ }^{5}$ Евалуацијским истраживањем утврђено је да су адолесценти укључени у програм и након четири године значајно ређе пријављивали и вршење и виктимизацију сексуалним насиљем (Foshee, Bauman, Ennett, Linder, Benerield \& Suchindran, 2004).
} 
љање нарушеног „поретка полова”, те да силоватеље не покреће толико сексуални нагон колико бес према жртви, жеља за одмаздом због жртвиног одбијања да се покори његовој вољи, или притисак из социјалног окружења да се потврди као мушкарац, макар тако што ће по сваку цену успоставити доминацију над женом постављајући је на „њено место”. Многи силоватељи верују да је принудно успостављање доминације над женом морално допуштено, јер је она одбијањем да се покори нарушила традиционални распоред моћи (Fiske \& Rai, 2015, p. 173). Не чуде зато налази да зависно од социокултурног амбијента варира не само стопа сексуалног насиља већ и вероватноћа појаве осећања кривице код извршиоца. Рецимо, истраживање недавно спроведено у шест азијских земаља (Jewkes, Fulu, Roselli\& Garcia-Moreno, 2013) показало је да је четвртина испитаних мушкараца старих између 18 и 49 година потврдила да је најмање једном присилила на обљубу своју партнерку или другу женску особу. Већина је сматрала да је на то имала право, а покренуло их је осећање љутње и жеља да казне жртву. Занимљиво је да је проценат оних који су осећали кривицу због силовања (мада је у просеку био нешто изнад 50\%) у већини земаља знатно премашивао вероватноћу како формалног санкционисања тако и моралног осуђивања извршиоца од стране окружења (Jewkeset al., 2013, p. 211, 213).

Будући да су промене на индивидуалном нивоу немогуће или неодрживе без промена на нивоу заједнице, превенција нужно захтева сарадњу различитих социјалних субјеката (Quadara \& Wall, 2012, pp. 5-6). С тим у вези, од значаја је поменути један од оквирних модела примарнопревентивне иницијативе који подразумева свеобухватан приступ и укљученост различитих субјеката у заједници, а који носи назив „Спектар превенције” (Sprectrum of Prevention). Модел је формулисао Коен (Cohen) из оуклендског Института за превенцију с циљем да помогне заједницама у развијању стратегија превенције насиља, а надахнут је идејом да је превенција више од едукације - она се разуме као синергија акција којима се подстичу промене на нивоу појединца и заједнице, односно симултаних интервенција усмерених на унапређење индивидуалних знања и вештина, едукацију пружалаца услуга, јачање сарадње, промену унутар организацијских пракси и развој законодавства и јавних политика (Davis et al., 2006).

Премда мере ситуационе превенције, уопште узев, немају далекосежан превентивни учинак, разуме се да су и оне важна компонента примарнопревентивних интервенција. У литератури се указује на то да се превентивни учинци могу постићи посебним дизајнирањем окружења, организовањем суседског надзирања, пратње за рањиве категорије особа, групног кретања деце на путу од куће до школе (Kaufman et al., 2006, према: Brown \& Saied-Tessier, 2015, p. 24-26), као и другим мерама усмереним на стварање сигурнијег окружења тако што се вршење одређених напада чини ризичнијим и тежим. 


\section{ЗАВРШНА ДИСКУСИЈА}

Проблем сексуалног насиља осетљив је на социјално-културни амбијент и могуће га је редуковати примарнопревентивним мерама. Примарна превенција није једино, можда ни најзахтевније поље превентивних активности у овој области, но, имајући у виду да се она основано сматра потенцијално најефективнијом стратегијом превенције, као друге њене предности попут обухватности, приуштивости, ниског ризика од штетних ефеката и избегавања стигматизације, одговоран приступ превенцији и заштити од насиља подразумева максимално исцрпљивање њених могућности. Ово пак обавезује на даља истраживања фактора и ваљано постимплементацијско вредновање интервенција, које мора постати стандардна пракса као гарант позитивног развоја превенције и одговорног односа носилаца превентивних активности према потребама и ресурсима заједнице.

У конципирању и имплементацији превентивних мера пресудна је сарадња на стратегијској основи, тј. симултано ангажовање различитих субјеката на националном и на нивоу локалне заједнице, као предуслов системских промена схватања и пракси које су у непосредној или посредној вези са проблемом сексуалног насиља и насиља уопште. Промовисање људских права, уз нагласак на добробити које појединац и заједница имају од поштовања принципа једнакости и неприхватљивости напада на психо-физички интегритет другог - дугорочан је задатак, али обећава трајне позитивне ефекте у будућности. Кључна жељена промена је став о насиљу као апсолутно неприхватљивом, те је важно кроз едукацију осветлити све његове аспекте, укључујући емоционалну подлогу, функције и циљеве оних који га примењују, како би се негативан став према насиљу темељио на опажању аморалности његове примене, уместо на пукој „освешћености" о његовој недопуштености у овом или оном социјалном контексту.

При разматрању утицаја културних норми и ставова на сексуално насиље, не треба губити из вида да се ни у друштвима са ригидном традиционалном расподелом моћи између полова већина мушкараца не понаша насилно у сексуалној сфери и да се сексуална насилност универзално третира као одступајуће понашање. Но, у друштвима са укорењеним стереотипима везаним за родне улоге, она се у многим конкретним случајевима толерише. Нелогично окривљавање жртве за сексуално насиље које је претрпела заправо рефлектује превагу моралног осуђивања жене због повреде традиционалног система родних улога над осуђивањем оног који примењује насиље над њом, метафорички је кажњавајући за ту повреду. Жене слободније у одевању и комуникацији, оне које конзумирају алкохол, иду у ноћне проводе, оне за које се верује да смишљено, ради забаве или користи заводе мушкарце - све оне које на неки начин одступају од родног стере- 
отипа исправне жене - изазивају интензивније негативне реакције него сексуални преступници о којима већина људи и нема јасну представу. Разлог минимизовања проблема сексуалног насиља не лежи у интимној привржености грађана пронасилним вредностима и нормама, већ у социјалним силама које одржавају њихову равнодушност, митове о мушкој солидарности и женској превртљивости, или пак погрешно усмеравају моралну узнемиреност. Медији ствар компликују неадекватним праћењем проблема, сексуализацијом насиља, али и необузданим третирањем женске лепоте као идеала са тржишном вредношћу и рабљењем маргиналних случајева као прототипа „мушког” и „женског” оличених у мачизму и сексуализовано-комерцијализованој женствености, чиме потпомажу одржавање родних стереотипа и доприносе учвршћивању ставова о прихватљивости насиља према женама.

Програми едукације младих као основна форма примарнопревентивних интервенција у замаху су развоја у многим земљама, а резултати досадашњих евалуација могу послужити као смернице. Поуке од значаја и за Србију јесу да је едукација важна, али недовољна за постизање циљева примарне превенције. Поред едукације у школама, подизања свести у јавности о коренима, факторима ризика и последицама насиља и промовисања људских права, здравих животних стилова и интерперсоналних односа, потребно је на стратегијској основи подстицати и развијати комплементарне компоненте примарне превенције, укључујући мере ситуационе превенције, кампање нулте толеранције према насиљу, активизам мушких антинасилних група, мере медијске саморегулације, програме обука самоодбране за жене (који би требало да буду промовисани и доступни у локалним заједницама), као и унапређивање нормативног оквира заштите од насиља и дискриминације у различитим окружењима.

Значај кампања нулте толеранције према сексуалном насиљу огледа се пре свега у негативним порукама које се шаљу потенцијалним извршиоцима, који ће бити подстакнути на уздржавање и промену тек кад вршење насиља почну да опажају као сигуран начин самодеструкције, уместо као најлакши пут да се разоноде или потврде „мушку част”. Јасно је да најупечатљивију поруку о „неисплативости" насиља могу послати законодавац, полиција и кривично правосуђе. Са становишта циљева примарне превенције, пооштравање казнене политике није довољно, али није ни нужно, имајући у виду општепревентивни учинак ефикасних и ефективних криминалистичких истрага и кривичних поступака. Том ефикасношћу шаље се најснажнија порука друштва, којом се обесхрабрују потенцијални извршиоци, а охрабрују жртве сексуалног насиља. 


\section{ЛИТЕРАТУРА}

Basile, K.C., Smith, S.G., Breiding, M.J., Black, M.C.\& Mahendra, R.(2014). Sexual Violence Surveillance: Uniform Definitions and Recommended Data Elements, Version 2.0. Atlanta (GA): National Center for Injury Prevention and Control, Centers for Disease Control and Prevention.

Brown, J. \& Saied-Tessier, A. (2015).Preventing Child Sexual Abuse: Towards a national strategy for England. London: NSPCC. Retrieved from https://www.nspcc.org.uk/globalassets/documents/research-

reports/preventing-child-sexual-abuse-towards-a-national-strategy.pdf

Casey, E. \& Lindhorst, T. (2009).Toward a multi-level, ecological approach to the primary prevention of sexual assault: Prevention in peer and community contexts, Trauma, Violence and Abuse, 10, 2, 91-114. doi: 10.1177/1524838009334129

Centers for Disease Control and Prevention (2004).Sexual violence prevention: beginning the dialogue. Atlanta, GA: Centers for Disease Control and Prevention.

Dahlberg, L.L. \& Krug, E.G. (2002). Violence - a global public health problem. In E. G. Krug et al. (Eds.), World Report on Violence and Health (pp. 3-21). Geneva: World Health Organization.

Daigle, L.E.\&Fisher, V.S. (2010). Rape. In B.B. Fisher, S.P. Lab (Eds.),Encyclopedia of Victimology and Crime Prevention (Vol. 2, pp. 708-715). Sage Publications, Inc.

Davis, R., Parks, L.F.\& Cohen, L.(2006). Sexual Violence and the Spectrum of Prevention: Towards a Community Solution. National Sexual Violence Resouce Center. Retrieved from www.nsvrc.org/sites/default/files/Publications_NSVRC_ Booklets_Sexual-Violence-and-the-Spectrum-of-Prevention_Towards-aCommunity-Solution_0.pdf

DeGue, S.,Valle, L.A., Holt, M. K.,Massetti, G. M., Matjasko, J. L.\& Tharp, A. T. (2014). A systematic review of primary prevention strategies for sexual violence prevention, Aggression and Violent Behavior, 19, 346-362. doi:10.1016/j.avb.2014.05.004

Dickson, S. \& Willis, G.M. (2015). Primary Prevention of Sexual Violence in Aotearoa New Zealand: A Survey of Prevention Activities, Sexual Abuse: A Journal of Research and Treatment, First published on April 30, 2015: 121.doi: $10.1177 / 1079063215583852$

Fiske, A.P. \& Rai, T.S. (2015).Virtuous Violence: Hurting and Killing to Create, Sustain, End, and Honor Social Relationships. Cambridge University Press.

Foshee, V.A., Bauman, K.E., Arriga, X. B., Helms, R.W., Koch, G.G. \& Linder, G.F. (1998). An Evaluation of Safe Dates, an Adolescent Dating Violence Prevention Program, American Journal of Public Health, 88, 1, 45-50.

Foshee, V.A., Bauman, K.E., Ennett, S.T., Linder, G.F., Benerield, T. \& Suchindran, C.(2004). Assessing the long-term effects of the Safe Dates program and a booster in preventing and reducing adolescent dating violence victimization and perpetration, American Journal of Public Health, 94, 4, 619-624.

Hanson, R.K. \& Harris, A.J.R. (2013). Criminogenic Needs of Sexual Offenders on Community Supervision, In L.A. Craig et al. (Eds.), What Works in Offender Rehabilitation: An Evidence-Based Approach to Assessment and Treatment. Wiley-Blackwell; Public Safety Canada.

Harvey, A, Garcia-Moreno, C.\& Butchart, A. (2007). Primary prevention of intimatepartner violence and sexual violence: Background paper for WHO expert meeting, May 2-3, 2007, WHO. Retrieved from www.who.int/violence_ injury_prevention/publications/violence/IPV-SV.pdf 
Jewkes, R, Sen, P. \& Garcia-Moreno, C. (2002). Sexual violence. In: E. G. Krug et al. (Eds.), World Report on Violence and Health (pp. 149-181). Geneva: World Health Organization.

Jewkes, R., Fulu, E., Roselli, T. \& Garcia-Moreno, C. (2013). Prevalence of and factors associated with non-partner rape perpetration: findings from the UN Multi-country Cross-sectional Study on Men and Violence in Asia and the Pacific, Lancet Global Health, 1, e208-218. doi: 10.1016/S2214-109X(13)70069-X

Mercado, C.C. \& Ogloff, J.R.P. (2007). Risk and the preventive detention of sex offenders in Australia and the United States, International Journal of Law and Psychiatry, 30, 49-59. doi:10.1016/j.ijlp.2006.02.001

Quadara, A, Wall, L. (2012).What is effective primary prevention in sexual assault? Translating the evidence for action. Commonwealth of Australia: Australian Centre for the Study of Sexual Assault, Issue 11.

Taylor, B., Stein, N.D., Woods, D.\& Mumford, E.(2011).Shifting Boundaries: Final Report on an Experimental Evaluation of a Youth Dating Violence Prevention Program in New York City Middle Schools. Washington: Police Executive Research Forum. Retrieved from https://www.ncjrs.gov/pdffiles1/nij/grants/ 236175.pdf

Tharp, A.T., DeGue, S., Valle, L.A., Brookmeyer, K.A., Massetti, G.M. \& Matjasko, J.L. (2012). A Systematic Qualitative Review of Risk and Protective Factors for Sexual Violence Perpetration, Trauma, Violence \& Abuse, 14, 2, 133-167. doi: $10.1177 / 1524838012470031$

Ullman, S.E. (2010). Protection against Rape. In B. B. Fisher, S. P. Lab (Eds.), Encyclopedia of Victimology and Crime Prevention (Vol. 2, pp. 726-727). Sage Publications, Inc.

Wall, L. (2013).Issues in evaluation of complex social change programs for sexual assault prevention. Commonwealth of Australia: ACSSA Issues, No. 14.

Whitaker, D. J., Le, B., Hanson, R.K., Baker, C.K., McMahon, P.M., Ryan, G., Klein, A.\& Rice, D.D.(2008). Risk factors for the perpetration of child sexual abuse: A review of meta-analysis. Child Abuse and Neglect, 32, 529-548. doi: 10.1016/j.chiabu.2007.08.005

World Health Organization (2013).Global and regional estimates of violence against women: Prevalence and health effects of intimate partner violence and nonpartner sexual violence. Geneva: WHO Document Production Services.

\title{
DEVELOPMENT OF SEXUAL VIOLENCE PRIMARY PREVENTION AROUND THE WORLD
}

\author{
Biljana Simeunović-Patić \\ The Academy of Criminalistic and Police Studies, Belgrade, Serbia
}

\section{Summary}

The seriousness of individual and societal consequences of sexual violence along with unsatisfactory effects of repressive and tertiary preventive measures towards sexual offenders refer to the importance of primary prevention, which is slowly gaining primacy in the spectrum of societal responses to sexual violence. Primary prevention is neither the only, nor the most demanding aspect of prevention of sexual violence. However, bearing in mind its advantages including wide coverage, relatively low costs, low risk of harmful 
effects and stigmatisation avoidance, all existing possibilities of primary prevention should be exhausted.

In the line with dominant understanding that sexual violence is determined by multiple risk factors at individual, interpersonal and social level whereby the cultural norms and values are considered to be highly influential to the incidence of violence, primary prevention efforts are mainly directed toward changing the cultural norms that support sexual violence or rigid traditional gender roles, and most often takes the form of education programs. Usually, education programs are not very costly, and can be easily created and implemented. However, they are only one component of primary prevention, insufficient to achieve preventive goals that go above and beyond knowledge sharing and awareness raising and include systematic changes of beliefs, attitudes and practices directly or indirectly linked to the problem of sexual violence, and violence in general.

In addition to school-level education programs and raising awareness and educating the public on the roots, risk-factors and consequences of violence, complementary components of prevention should be also developed, including the measures of situational prevention, zero-tolerance campaigns toward violence, men anti-violence group activism, measures of media self-regulation, self-defence training for women, as well as improvements of normative framework of protection from violence in various social environments.

Finally, further research on risk and protective factors is necessary, while postimplementation evaluation of intervention should be the standard practice as a guaranty of positive development of prevention and prevention activities proponents' respect toward community needs and resources. 